\title{
Isalonactis, a new genus of Roccellaceae (Arthoniales), from southern Madagascar
}

\section{Damien ERTZ, Anders TEHLER, Eberhard FISCHER, Dorothee KILLMANN, Tahina RAZAFINDRAHAJA and Emmanuël SÉRUSIAUX}

\begin{abstract}
The new genus and species Isalonactis madagascariensis is characterized by a crustose, noncorticate, often sorediate thallus containing psoromic acid, tiny white pruinose ascomata with a thalline margin, an inconspicuous excipulum, a pale brown hypothecium, 3-septate hyaline ascospores and curved filiform conidia. Phylogenetic analyses using nuLSU and RPB2 sequences place Isalonactis in the Roccellaceae, close to the genera Lecanactis and Chiodecton. The new species was collected on sheltered siliceous rocks in the dry landscape of the Isalo Massif (S Madagascar). Dermatiscum thunbergii is newly recorded from Madagascar.
\end{abstract}

Key words: Africa, Arthoniomycetes, desert, Lecanactis, lichen, phylogeny, taxonomy

\section{Introduction}

Madagascar is a large island situated in the Indian Ocean at a minimum distance of 400 $\mathrm{km}$ from the African continent. It is well known for its remarkable biodiversity including many endemic taxa (Goodman \& Benstead 2003). Despite the island being one of the most important biodiversity hotspots (Myers et al. 2000), its lichen flora remains very poorly studied with only 157 species included in the only available checklist (Aptroot 2013). This number contrasts with the 463 lichen taxa reported recently from

D. Ertz (corresponding author): Jardin Botanique National de Belgique, Département Bryophytes-Thallophytes, Domaine de Bouchout, B-1860 Meise, Belgium. Email: damien.ertz@br.fgov.be

A. Tehler: Naturhistoriska riksmuseet, Enheten för kryptogambotanik, Box 50007, S-104 05 Stockholm, Sweden.

E. Fischer and D. Killmann: Institute for Integrated Natural Sciences, Department of Biology, University of Koblenz-Landau, Universitätstraße 1, D-56070 Koblenz, Germany.

T. Razafindrahaja: Département Botanique, Parc de Tsimbazaza, B.P. 4096, Antananarivo 101, Madagascar. E. Sérusiaux: Evolution and Conservation Biology, University of Liège, Sart Tilman B22, B-4000 Liège, Belgium. the neighbouring and much smaller island of Reunion (van den Boom et al. 2011). During a field trip in 2008, five of the authors (DE, EF, DK, TR and ES) were able to prospect several biomes, for example montane rainforests, dry forests, semideserts with rock outcrops, and detected numerous new records for the island. Most of these were widespread species not confined to Madagascar. However, the study of our material enabled us to describe the new lichen genus Savoronala Ertz et al., forming stipes producing sporodochia and thriving on Erica stumps and branches in heathlands in coastal sand dunes (Ertz et al. 2013). New lichen species were also discovered such as Syncesia madagascariensis Ertz et al., one of the few species of the genus having ascospores with more than three septa (Ertz et al. 2010), and Dirina madagascariensis Tehler et al., a cryptic species revealed by a detailed phylogenetic study of the genus (Tehler et al. $2013 a$ ). Further study of our material revealed a puzzling sorediate crustose member of the Roccellaceae collected in the semidesert landscape of the Isalo Massif. The aim of the present paper is to describe it and assess its phylogenetic position. 


\section{Material and Methods}

Specimens were studied using an Olympus SZX12 stereomicroscope and an Olympus BX51 microscope. Hand-cut sections were investigated using light microscopy on material mounted in water and $5 \% \mathrm{KOH}$. Measurements of ascospores and conidia refer to material examined in water, those of asci to material examined in $\mathrm{K} / \mathrm{I}$. Ascospore measurements are indicated as (minimum-) $\bar{x}-\mathrm{SD}-\bar{x}+\mathrm{SD}$ (-maximum), where $\bar{x}$ is the mean value and SD standard deviation, followed by the number of measurements $(n)$. Chemical reactions were tested using $\mathrm{KOH}(\mathrm{K})$ and Lugol's reagent either without (I) or with (K/I) pre-treatment with $\mathrm{K}$. Thinlayer chromatography (TLC) of acetone extracts was performed in solvent systems C and G (Orange et al. 2001).

We used DNA sequences from two loci, the nuclear large subunit ribosomal RNA gene (nuLSU), and the second largest RNA polymerase subunit (RPB2), of which six were newly produced for this study (Table 1 ). Other sequences were mainly sampled from a previously published larger dataset of Arthoniales including the family Roccellaceae (Ertz \& Tehler 2011), with a few additional sequences from Tehler et al. (2013b). The two datasets were analyzed both separately and combined. Extractions, amplifications and sequencing procedures generally follow Ertz et al. (2009, 2011). Alignments were carried out with ClustalW (2.1) from within the program Mesquite v.2.75 (http://mesquiteproject.org).

For the phylogenetic analyses, we used the programs T.N.T. Tree Analysis Using New Technology 1.1 (Goloboff et al. 2008) and MrBayes 3 (Ronquist \& Huelsenbeck 2003). In all analyses gaps were treated as missing data.

The parsimony analyses used the New Technology search with sectorial search, ratcheting, drifting, tree fusing and driven search options in effect, all using default settings. Resampling tree searches was done with parsimony jackknifing (Farris et al. 1996) under the New Tech search as implemented in T.N.T. (Goloboff et al. 2008); 1000 replicates submitted to TBR branch swapping were conducted. In parsimony jackknifing, the data are internally resampled with a jackknifing technique to find well-supported groups. Resampling works by calculating a tree for each of a large number of subsamples (pseudoreplicates) of characters from the data, then finding a summary tree, which comprises the groups occurring in the majority of the trees for subsamples. The tree for each pseudoreplicate is found by parsimony analysis, and each pseudoreplicate is formed by randomly selecting characters from the data without replacement, each character having a fixed chance $1 / \mathrm{e}$ (about $36 \%$ ) of being excluded. With this resampling technique, the actual number of characters used may vary from replicate to replicate. Groups found in less than $50 \%$ of the trees for pseudoreplicates were discarded, thus eliminating unjustified (poorly supported) resolution caused by ambiguous datasets.
In the Bayesian inference analyses, the best model for nucleotide substitutions was selected for each locus individually by applying the Akaike Information Criterion (AIC; Akaike 1973) and the program MrModeltest 2.2 (Nylander 2005) in conjunction with PAUP* (Swofford 1998). The selection of substitution models supported the GTR $+\mathrm{I}+\Gamma$ model for both partitions. Posterior probabilities of trees and parameters in the substitution models were approximated with MCMC and Metropolis coupling using the program MrBayes 3.2.1 (Ronquist \& Huelsenbeck 2003). The Bayesian analyses were run for 10 million generations with two independent runs and four chains of Markov chain Monte Carlo (MCMC). The burn-in and convergence diagnostics were estimated using the PSRF (potential scale reduction factor), where values closer to 1 indicated convergence between runs (Gelman \& Rubin 1992), and TRACER (Rambaut \& Drummond 2007), making sure that the ESS values were higher than 200 . The final majority-rule tree obtained from the Bayesian analyses is based on 17000 trees from the posterior of the two runs.

\section{Results}

Altogether we analyzed nuLSU rDNA and RPB2 sequences from two newly sequenced samples of Isalonactis madagascariensis (newly described below) and one newly sequenced sample of Chiodecton leptosporum Müll. Arg., together with 43 samples representing 40 other already phylogenetically analyzed species of Roccellaceae. In addition, three outgroup species were chosen among the Opegraphaceae (Ertz \& Tehler 2011; Tehler et al. 2013b). Parsimony jackknife analysis showed that the individual gene trees were topologically similar, with no conflicts detected, although the nuLSU tree was more poorly resolved.

Since there were no conflicts in tree topology between the trees received from the Bayesian inference and the Parsimony jackknife analyses, we chose for the sake of simplicity to plot the Parsimony jackknife frequencies directly onto the Bayesian tree which was more highly resolved (Fig. 1). In the Bayesian tree, Isalonactis (newly described below) appears as a monophyletic group in a sister group relationship with the genus Lecanactis, and the next larger group includes the genus Chiodecton as sister group. In the Parsimony jackknife tree (not shown), these three genera were left unresolved in a trichotomy. 
TABLE 1. Specimens used in phylogenetic analyses of the Arthoniales. GenBank accession numbers in bold are new sequences from this study.

\begin{tabular}{|c|c|c|c|c|c|c|}
\hline \multirow[b]{2}{*}{ Species } & \multirow[b]{2}{*}{ Locality } & \multirow[b]{2}{*}{ Year } & \multirow[b]{2}{*}{ Collector } & \multirow{2}{*}{$\begin{array}{c}\text { Collection } \\
\text { no. }\end{array}$} & \multicolumn{2}{|c|}{ Genbank Acc. No. } \\
\hline & & & & & nuLSU & $\mathrm{RPB} 2$ \\
\hline Austroroccella gayana & Chile, Los Lagos, Chiloe Prov., Ancud & 2009 & Anders Tehler & 9852 & KF036031 & KF036042 \\
\hline A. gayana & Chile, Los Lagos, Bahia Mansa & 2009 & Anders Tehler & $9855-3$ & KF036032 & KF036043 \\
\hline Chiodecton natalense & Zambia, SE of Mbala & 2004 & Damien Ertz & 6576 & EU704085 & EU704014 \\
\hline C. leptosporum & Reunion, Saint-Denis & 2012 & Damien Ertz & 17886 & KF831578 & KF831579 \\
\hline Dendrographa decolorans & Spain, Mallorca, Cala Figuera & 2007 & Anders Tehler & 9019 & HQ454603 & HQ454743 \\
\hline D. conformis & Mexico, Baja California, Ensenada, Pta Banda & 2007 & Anders Tehler & 9083 & HQ454590 & HQ454730 \\
\hline D. leucophaea & Mexico, Baja California, Ensenada, Pta Banda & 2007 & Anders Tehler & 9104 & HQ454522 & HQ454662 \\
\hline Dictyographa varians & Socotra, Sefflah & 2008 & Anders Tehler & 9346 & HQ454576 & HQ454716 \\
\hline Dirina candida & Mallorca, Playa de Cala Santanyí & 2007 & Anders Tehler & 9004 & KC108261 & KC108065 \\
\hline D. catalinariae & Mexico, Baja California, Ensenada, Pta Banda & 2007 & Anders Tehler & 9087 & GU137909 & GU137543 \\
\hline D. ceratoniae & Mallorca, Ses Covetes & 2007 & Anders Tehler & 9047 & FJ638966 & FJ639025 \\
\hline D. massiliensis & Sweden, Gotland, Hoburgen & 2007 & Anders Tehler & 9211 & KC108356 & KC108163 \\
\hline Enterographa crassa & France, Pas-de-Calais & 2003 & Damien Ertz & 5041 & EU704088 & EU704020 \\
\hline E. hutchinsiae & Belgium, Bohan-Membre & 2006 & Damien Ertz & 10066 & EU704089 & EU704021 \\
\hline Erythrodecton granulatum & Gabon, Makokou & 2006 & Damien Ertz & 9908 & EU704090 & EU704022 \\
\hline Isalonactis madagascariensis & Madagascar, Isalo Massif & 2008 & Damien Ertz et al. & 13021 & KF831576 & KF831580 \\
\hline I. madagascariensis & Madagascar, Isalo Massif & 2008 & Damien Ertz et al. & 13024 & KF831577 & KF831581 \\
\hline Lecanactis abietina & Sweden, Uppland, Svartnö & 2004 & Anders Tehler & 8550 & EF081392 & DQ987635 \\
\hline L. borbonica & Reunion, sud de Saint-Denis/Le Brûlé & 2003 & Damien Ertz & 4780 & EU704092 & EU704024 \\
\hline L. luteola & Chile, Antofagasta Prov., Cerro Moreno & 2009 & Anders Tehler & 9926 & HQ454595 & HQ454735 \\
\hline Opegrapha vulgata & Belgium, Roisin & 2005 & Damien Ertz & 7564 & EU704108 & EU704044 \\
\hline Roccella fuciformis & Portugal, Estremadura, Cabo da Roca & 2010 & Anders Tehler & 10200 & KF036035 & KF036046 \\
\hline R. gracilis & Peru, Dept. Pacasmayo, Cerro Chilco & 2006 & Anders Tehler & 8892 & FJ638983 & FJ639042 \\
\hline R. montagnei & Kenya, Kilifi distr., Mida Creek & 2007 & Anders Tehler & $9235-11$ & GU137967 & GU137601 \\
\hline R. phycopsis & France, Var, Isles d'Hyeres, Isle de Port-Cros & 2008 & Anders Tehler & 9511 & KF036036 & KF036047 \\
\hline R. tinctoria & Canary Islands, Tenerife, Buenavista del Norte & 2001 & Anders Tehler & 8308 & KF036037 & KF036048 \\
\hline Roccellina accedens & Chile, Coquimbo Prov., Bahia Conchali, & 2001 & Anders Tehler & 8451 & EF081432 & DQ987675 \\
\hline R. cerebriformis & Chile, Coquimbo Prov., 22 km N La Serena & 2001 & Anders Tehler & 8386 & HQ454585 & HQ454725 \\
\hline R. chalybea & Chile, Valparaiso Prov., Los Molles, Punta Molles & 2001 & Anders Tehler & 8355 & HQ454589 & HQ454729 \\
\hline R. hypomecha & South Africa, Western Cape Prov., Yzerfontein & 1996 & Anders Tehler & 7785 & EF081438 & DQ987681 \\
\hline R. inaequabilis & Chile, Coquimbo Prov., Parque Nacional Fray Jorge & 2001 & Anders Tehler & 8368 & EF081439 & DQ987682 \\
\hline R. limitata & Chile, Coquimbo Prov., Guanaqueros & 2001 & Anders Tehler & 8375 & EF081440 & DQ987683 \\
\hline R. mahuiana & Chile, Valparaiso Prov., Rocas de Santo Domingo & 2001 & Anders Tehler & 8459 & HQ454596 & HQ454736 \\
\hline R. mollis & Chile, Coquimbo Prov., Tongoy & 2001 & Anders Tehler & 8372 & EF081443 & DQ987686 \\
\hline R. portentosa & Chile, Valparaiso Prov., Los Molles, Punta Molles & 2001 & Anders Tehler & 8350 & EF081446 & DQ987689 \\
\hline R. terrestris & Chile, Antofagasta Prov., Cerro Moreno & 2009 & Anders Tehler & 9917 & HQ454598 & HQ454738 \\
\hline Schismatomma dirinellum & Spain, Mallorca, Ses Covetes & 2007 & Anders Tehler & 9051 & HQ454611 & HQ454751 \\
\hline S. dirinellum & Spain, Andalucia, Cádiz distr., $\mathrm{N}$ of Barbate & 2009 & Anders Tehler & $9815-10$ & KF036039 & KF036050 \\
\hline S. pericleum & Sweden, Uppland, Furusund & 2004 & Anders Tehler & 8551 & EF081451 & DQ987694 \\
\hline Sigridea californica & Mexico, Baja California, Ensenada, Pta Banda & 2007 & Anders Tehler & 9095 & HQ454637 & HQ454777 \\
\hline S. californica & Mexico, Baja California, Punta Banda & 2007 & Anders Tehler & 9110 & HQ 454638 & HQ454778 \\
\hline Sparria endlicheri & Belgium, Brûly-de-Pesche, vallée de l'Eau Noire & 2008 & Damien Ertz & 12651 & HQ454511 & HQ454652 \\
\hline Syncesia hawaiiensis & USA, Hawaii, Hawaii, North Kona Distr., Kalaoa & 2010 & Anders Tehler & $10156-27$ & KF036040 & KF036051 \\
\hline S. intercedens & Rwanda, forêt de Nyungwe & 2007 & Damien Ertz & 11059 & HQ454644 & HQ454784 \\
\hline S. madagascariensis & Madagascar, Ambalamanakana, Ankazomivady & 2008 & Damien Ertz & 12966 & HQ454645 & HQ454785 \\
\hline S. myrticola & Portugal, Azores, Terceira, Quatro Ribeiras & 2010 & Anders Tehler & 10252 & KF036041 & KF036052 \\
\hline
\end{tabular}




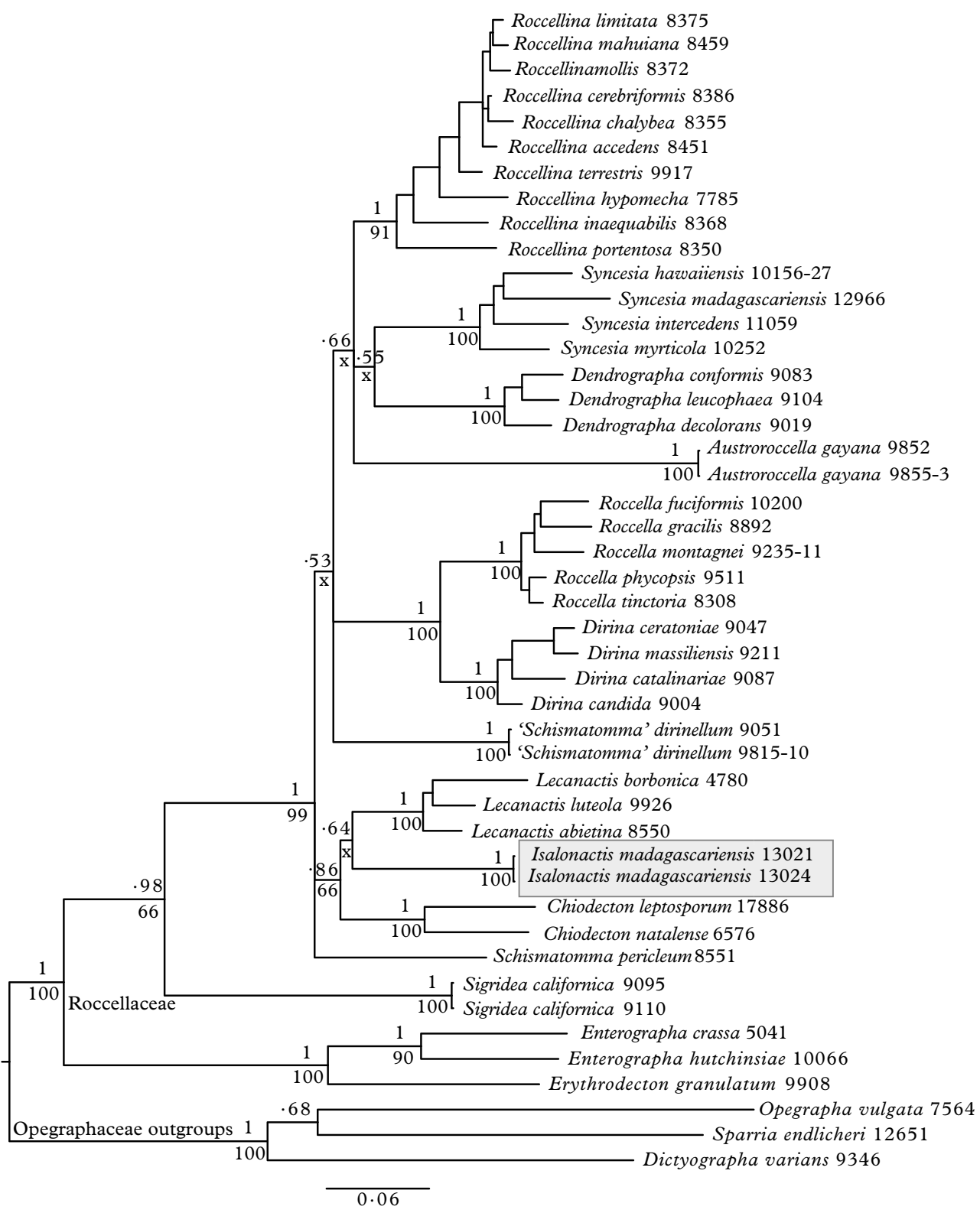

FIG. 1. Two-locus (nuLSU + RPB2) majority-rule tree received from Bayesian analysis showing the proposed phylogenetic relationships among 46 specimens representing 37 species of Roccellaceae with three species of Opegraphaceae (Opegrapha vulgata, Dictyographa varians and Sparria endlicheri) chosen as outgroups. Bayesian posterior probability values shown above nodes. Parsimony jackknife frequencies received from parsimony analyses were plotted below nodes $(\mathrm{x}=$ frequency below 50\%). For readability, values and frequencies are shown for genera and larger groups only. Collecting numbers of the authors following the species names act as specimen and sequence identifiers. Species within single quotes are names for which we regard recombination in a more appropriate genus as premature and thus the old name is retained. 
Isalonactis madagascariensis Ertz, Tehler, Eb. Fisch., Killmann, Razafin. \& Sérus. gen. et sp. nov.

\section{MycoBank No.: MB807014 (genus) and MB807015 (species)}

Taxon belonging to the Roccellaceae and characterized by the combination of the following characters: crustose, non-corticate, cracked to areolate thallus $c .0 \cdot 2-0.7 \mathrm{~mm}$ thick containing psoromic acid, tiny ascomata having a thalline margin, a white pruinose hymenial disc, an inconspicuous excipulum and a pale brown hypothecium, 3-septate hyaline ascospores of (20.0-)22.5-27.0 $(-29 \cdot 0) \times(4 \cdot 5-) 5 \cdot 0-5 \cdot 5(-6 \cdot 0) \mu \mathrm{m}$, and curved to sickleshaped filiform conidia.

Type: Madagascar, Isalo Massif near ANGAP house and National Park border, $851 \mathrm{~m}$ alt., $22^{\circ} 37^{\prime} 8 \cdot 1^{\prime \prime} \mathrm{S}$, $45^{\circ} 21^{\prime} 42 \cdot 6^{\prime \prime} \mathrm{E}$, Mesozoic sandstone cliffs with Coleochloa setifera, Ischnolepis tuberosa and Pachypodium gracilius, on sheltered rock, 7 October 2008, D. Ertz 13024, E. Fischer, D. Killmann, T. Razafindrahaja E E. Sérusiaux (BR-holotype; $\mathrm{S}$-isotype).

\section{(Fig. 2)}

Thallus epilithic, thin, non-corticate, c. $0 \cdot 2$ $0.7 \mathrm{~mm}$ thick, smooth, finely cracked to areolate, pale cream, matt; presence of numerous hyaline crystals $0.5-3.0 \mu \mathrm{m}$ diam. covering the hyphae, dissolving in $\mathrm{K}$ (polarized light); prothallus absent or dark brown, up to 0.5 $\mathrm{mm}$ wide. Photobiont Trentepohlia; cells 11$20 \times 8-12 \mu \mathrm{m}$.

Ascomata apothecioid, circular to irregular in outline, sometimes with an undulated or folded margin, scattered, erumpent, semiimmersed to sessile, not or slightly constricted at the base, usually one per areole, $(0 \cdot 2-) 0 \cdot 3-0 \cdot 5(-0 \cdot 8) \mathrm{mm}$ diam., with a thin non-corticate thalline margin of $50-70 \mu \mathrm{m}$ thick, level with the hymenial disc, of the same colour as the thallus; hymenial disc exposed, pale brown, covered by a white pruina. Exciple inconspicuous. Hymenium 85-110 $\mu \mathrm{m}$ tall, hyaline, not inspersed with oil droplets, I+ red, K/I+ blue; epihymenium pale to dark reddish brown, $\mathrm{K}-$ (but reddish tinge disappearing); hypothecium 75-150 $\mu \mathrm{m}$ tall, pale to dark brown, I- (orange), K(but reddish tinge disappearing). Paraphysoids sparsely branched in the hymenium, richly branched in the epihymenium, $2 \mu \mathrm{m}$ thick, not or only slightly enlarged at apices; apices dark brown, 5-15 $\mu \mathrm{m}$ long. Asci clavate, 55-
$65 \times 15-16 \mu \mathrm{m}, 8$-spored, K/I- except for an amyloid (blue) endoascus layer in the upper part. Ascospores (20.0-)22.5-27.0 $(-29 \cdot 0) \times(4 \cdot 5-) 5 \cdot 0-5 \cdot 5(-6 \cdot 0) \mu \mathrm{m}(n=23)$, (2-)3-septate, septation starting with one median septum, not constricted at septa, cells more or less equal in size; gelatinous sheath absent (at $\times 1000)$.

Pycnidia immersed in the thallus, visible as pale to dark brown punctiform spots 40-70 $\mu \mathrm{m}$ diam, c. $200 \times 100 \mu \mathrm{m}$; pycnidia wall very thin, hyaline to pale brown; conidia filiform, slightly curved to sickle-shaped, 12$23 \times 1 \mu \mathrm{m}$.

Chemistry. Thallus $\mathrm{K}-, \mathrm{C}-, \mathrm{P}+$ yellow, UV- or \pm pale cream; TLC (solvents $C$ and $\mathrm{G}$ ): psoromic acid (specimens tested: holotype and Ertz 13021).

Etymology. Isalonactis refers to the remarkable Isalo Massif (type locality) and the close relationship to the genus Lecanactis.

Ecology and distribution. Isalonactis madagascariensis is known only from the type locality in Madagascar, situated $180 \mathrm{~km}$ from the nearest coast. It grows on sheltered siliceous rocks in an arid landscape, with a poorly-developed Roccella montagnei, a fruticose species widely distributed in the Palaeotropics and having a preference for coastal habitats (Tehler et al. 2010, including two specimens sequenced from the Isalo Massif). Other lichens collected from the same locality are Xanthoparmelia tananarivensis (Gyeln.) Hale, and members of the genera Buellia, Caloplaca, Pertusaria, Pyxine, Parmotrema, Toninia, Usnea and Xanthoparmelia. The type locality is situated just outside Isalo National Park which forms a Jurassic sandstone massif. The rocks have been subjected to erosion and form steep slopes and canyons. Isalo Massif is famous for its endemics. In addition to widespread Malagasy endemics such as Coleochloa setifera (Ridl.) Gilly (Cyperaceae) and Ischnolepis tuberosa Jum. \& $\mathrm{H}$. Perrier (Rubiaceae), numerous local endemic plant species are known from this area. Among palms (Dransfield \& Beentje 1995), Ravenea rivularis Jum. \& H. Perrier, $R$. glauca Jum. \& H. Perrier and Dypsis onilahensis 

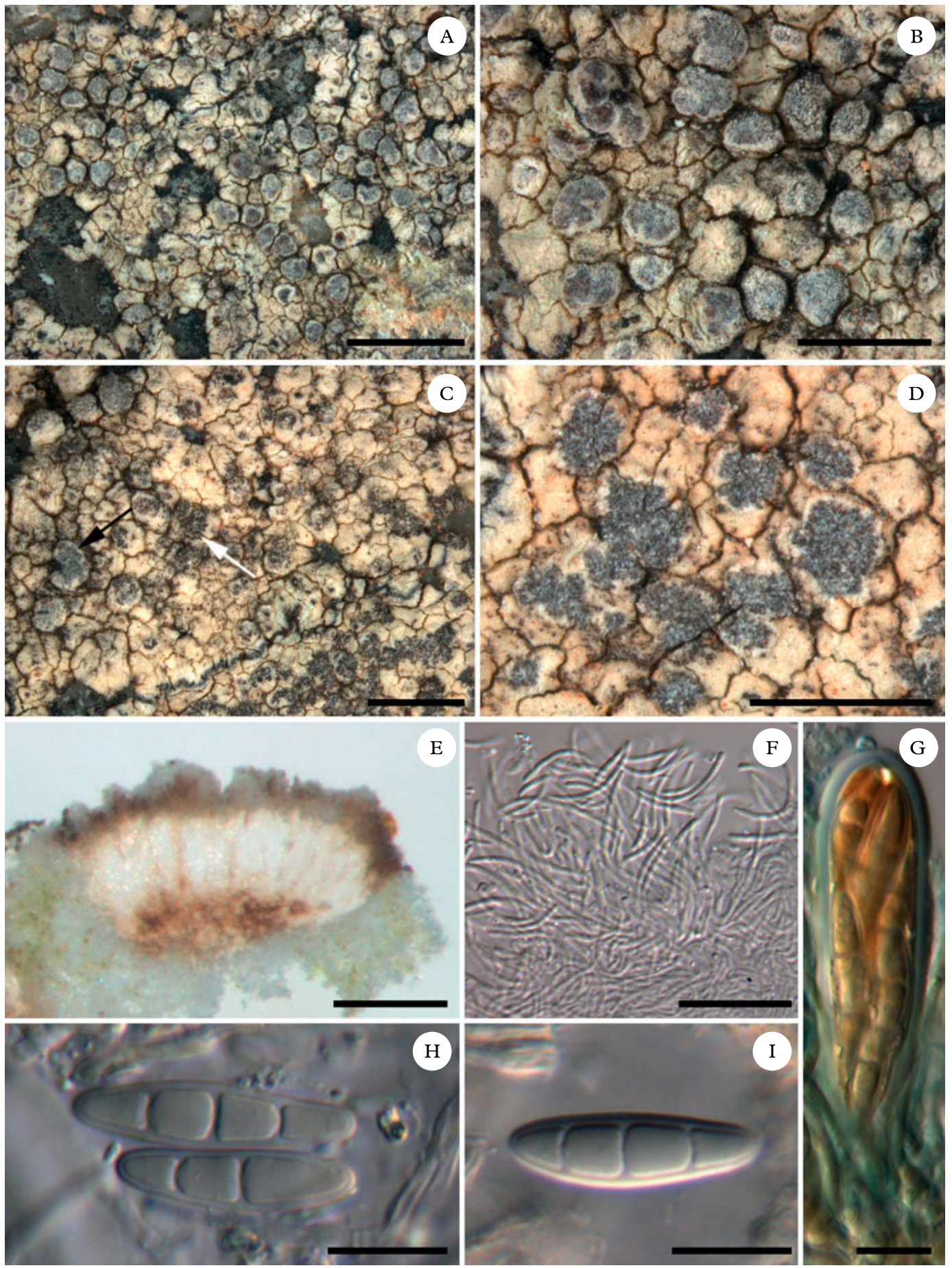

Fig. 2. A-I, Isalonactis madagascariensis (A-C, E-I, holotype; D, Ertz 13021). A \& B, thallus and apothecia; C, thallus bearing both soredia (white arrow) and apothecia (black arrow), and separated by a black, prothallus borderline from a sorediate thallus at the lower right corner of the photograph; D, thallus and soredia; E, section through an apothecium in water; F, conidia in water; G, ascus in KI; H \& I, ascospores in water. Scales: A = 2 mm; $\mathrm{B}-\mathrm{D}=1 \mathrm{~mm} ; \mathrm{E}=250 \mu \mathrm{m} ; \mathrm{F}=20 \mu \mathrm{m} ; \mathrm{G}-\mathrm{I}=10 \mu \mathrm{m}$. In colour online. 
(Jum. \& H. Perrier) Beentje \& J. Dransf. are almost restricted to Isalo. As members of the endemic families Asteropeiaceae and Sarcolaenaceae, the following shrubs are either endemic to Isalo or found in few other localities: Asteropeia labatii G. E. Schatz et al., Perrierodendron occidentale (Capuron) J. F. Leroy et al., Sarcolaena isaloensis Randrianasolo \& J. S. Miller, S. oblongifolia F. Gérard, Schizolaena isaloensis Rabehevitra \& Lowry, Xerochlamys undulata Hong-Wa and $X$. villosa F. Gérard (Ramananjanahary et al. 2010). Endemic or near endemic Xerophyta-species (Velloziaceae) are Xerophyta croatii Phillipson \& Lowry, $X$. isaloensis Phillipson \& Lowry, X. schatzii Phillipson \& Lowry and $X$. setosa Phillipson \& Lowry (Behnke et al. 2013). The sandstone rock outcrops are especially famous for numerous endemic succulents such as Pachypodium gracilius (H. Perrier) Rapan., Aloe isaloensis H. Perrier, Ceropegia dimorpha Humbert, C. pseudodimorpha Rauh, Cynanchum macrolobum Jum. \& H. Perrier and C. rauhianum Descoings (Rauh 1995, 1998). The Isalo Massif also harbours a large number of endemic species of amphibians and reptiles (Crottini et al. 2008). It must be noted that the very peculiar Dermatiscum thunbergii (Ach.) Nyl. was found in a similar dry landscape, on a granitic inselberg opposite Anja Nature Reserve $[12 \mathrm{~km} \mathrm{~S}$ of Ambalavao, $21^{\circ} 50^{\prime} 45 \cdot 4^{\prime \prime} \mathrm{S}, \quad 46^{\circ} 50^{\prime} 21 \cdot 8^{\prime \prime} \mathrm{E}, 972 \mathrm{~m}, 5$ October 2008, Ertz 12987 (BR), Sérusiaux s. n.(LG)]. This member of Physciaceae was only known from the southern part of continental Africa. It is newly recorded here from Madagascar.

Notes. As shown in our phylogenetic tree (Fig. 1), Isalonactis madagascariensis is most closely related to the genera Lecanactis and Chiodecton. It differs from Lecanactis by apothecia having a thalline margin with a pale brown hypothecium, whereas species of Lecanactis have a lecideine exciple with a usually dark brown to carbonized hypothecium. No species of Lecanactis are known to be sorediate. In the holotype specimen of Isalonactis madagascariensis, thalli might have either apothecia or soredia, but one thallus has both (Fig. 2C). In the specimen Ertz
13021, thalli are sorediate but one thallus has both soredia and apothecia, clearly indicating that sterile, sorediate morphs and fertile morphs are conspecific. Psoromic acid is rare in the genus Lecanactis, being known only in two species L californica and L. dilleniana (Egea \& Torrente 1994), but sequences obtained from the latter suggest that it belongs to another genus (D. Ertz, A. Tehler, M. Irestedt, A. Frisch, G. Thor \& P. van den Boom, unpublished data). The ascomata of Isalonactis being sometimes undulated with a strongly folded margin might be reminiscent of the genera Chiodecton or Syncesia. However, Chiodecton species (represented in our phylogenetic tree by the only species for which sequences are currently available, i.e. C. natalense, and by a newly sequenced species, C. leptosporum) differ from our new genus by perithecioid to lirelliform ascomata aggregated into stroma-like structures, obovate or slightly biclavate ascospores and a different chemistry, roccellic acid (Thor 1990). The generic type, $C$. sphaerale Ach., still needs to be sequenced in order to confirm the phylogenetic position of the genus Chiodecton. However, that species has long, narrow $(30-37 \times 2-3 \mu \mathrm{m})$ and obovate ascospores, and roccellic acid in the thallus (Thor 1990). Therefore it is most probably not congeneric with Isalonactis. The genus Syncesia forms a distinct, quite distantly related lineage to our new genus (Fig. 1; the generic type, $S$. myrticola, being included) and differs usually by curved, longer and slender ascospores in addition to a different chemistry (presence of protocetraric and roccellic acids in nearly all species, including the generic type) (Tehler 1997). The new genus and species might be reminiscent of the genus Sigridea due to the 3-septate ascospores lacking a gelatinous sheath, the thalline margin and the presence of psoromic acid. However, species of the latter genus differ from Isalonactis madagascariensis by a carbonized hypothecium and much shorter, up to $7 \mu \mathrm{m}$ conidia (Tehler 1993). Moreover, the generic type of Sigridea ( $S$. californica) is phylogenetically not related to our new genus (Fig. 1). The sorediate thalli of 
our new taxon is similar to Fulvophyton sorediata (Sparrius et al.) van den Boom, but that species has immersed ascomata and very different ascospores, being (4-)6-8septate, $20-35 \times 5-7 \mu \mathrm{m}$ with a distinct gelatinous sheath c. $3.5 \mu \mathrm{m}$ wide (van den Boom \& Giralt 2012). We also checked that no older generic names of Arthoniales were available to accommodate our new species.

Additional specimen examined. Madagascar: Isalo Massif near ANGAP house and National Park border, $851 \mathrm{~m}$ alt., $22^{\circ} 37^{\prime} 8 \cdot 1^{\prime \prime} \mathrm{S}, 45^{\circ} 21^{\prime} 42 \cdot 6^{\prime \prime} \mathrm{E}$, Mesozoic sandstone cliffs with Coleochloa setifera, Ischnolepis tuberosa and Pachypodium gracilius, on sheltered rock, 7 October 2008, D. Ertz 13021, E. Fischer, D. Killmann, T. Razafindrahaja E̊ E. Sérusiaux s. n. (BR, LG).

We are indebted to the staff of the Parc Botanique et Zoologique de Tsimbazaza in Antananarivo for logistical support. We would like to thank the Ministère des Eaux et Forêts for collection and export permits for scientific material. Cyrille Gerstmans, Wim Baert and Myriam de Haan are thanked for technical assistance. Finally, the authors acknowledge financial support from the Fonds National de la Recherche Scientifique (FNRS) from Belgium (F.R.F.C. \# 2.4515.06).

\section{ReFERENCES}

Akaike, H. (1973) Information theory as an extension of the maximum likelihood principle. In Proceedings of the Second International Symposium on Information Theory (B. N. Petrov \& F. Csaki, eds): 267-281. Budapest: Akademiai Kiado.

Aptroot, A. (1990) Lichens of Madagascar: new and interesting records and species. Cryptogamie, Bryologie et Lichénologie 11: 401-408.

Aptroot, A. (2013) Checklist of lichens and lichenicolous fungi of Madagascar. Available at http://www.biologie.uni-hamburg.de/checklists/lichens/africa/madagascar_l.htm. Accessed 16 October 2013.

Behnke, H. D., Hummel, E., Hillmer, S., Sauer-Gürth, H., Gonzalez, J. \& Wink, M. (2013) A revision of African Velloziaceae based on leaf anatomy characters and $r b c L$ nucleotid sequences. Botanical fournal of the Linnean Society 172: 22-94.

Crottini, A., Chiari, Y., Mercurio, V., Meyer, A., Vences, M. \& Andreone, F. (2008) Into the canyons: the phylogeography of the Malagasy frogs Mantella expectata and Scaphiophryne gottlebei in the arid Isalo Massif, and its significance for conservation (Amphibia: Mantellidae and Microhylidae). Organisms Diversity and Evolution 8: 368-377.

Dransfield, J. \& Beentje, H. (1995) The Palms of Madagascar. Kew: Royal Botanic Gardens.

Egea, J. \& Torrente, P. (1994) El género de hongos liquenizados Lecanactis (Ascomycotina). Bibliotheca Lichonologica 54: 1-205.
Ertz, D. \& Tehler, A. (2011) The phylogeny of Arthoniales (Pezizomycotina) inferred from nucLSU and RPB2 sequences. Fungal Diversity 49: 47-71.

Ertz, D., Miądlikowska, J., Lutzoni, F., Dessein, S., Raspe, O., Vigneron, N., Hofstetter, V. \& Diederich, P. (2009) Towards a new classification of the Arthoniales (Ascomycota) based on a three-gene phylogeny focusing on the genus Opegrapha. Mycological Research 113: 141-152.

Ertz, D., Killmann, D., Razafindrahaja, T., Sérusiaux, E. \& Fischer, E. (2010) Two new species of Syncesia (Arthoniales, Roccellaceae) from Africa. Lichenologist 42: 43-49.

Ertz, D., Bungartz, F., Diederich, P. \& Tibell, L. (2011) Molecular and morphological data place Blarneya in Tylophoron (Arthoniaceae). Lichenologist 43: 345356.

Ertz, D., Fischer, E., Killmann, D., Razafindrahaja, T. \& Sérusiaux, E. (2013) Savoronala, a new genus of Malmideaceae (Lecanorales) from Madagascar with stipes producing sporodochia. Mycological Progress 12: 645-656.

Farris, J. S., Albert, V. A., Källersjö, M., Lipscomb, D. L. \& Kluge, A. G. (1996) Parsimony jackknifing outperforms neighbor-joining. Cladistics 12: 99-124.

Gelman, A. \& Rubin, D. B. (1992) Inference from iterative simulation using multiple sequences. Statistical Science 7: 457-511.

Goloboff, P. A., Farris, J. S. \& Nixon, K. C. (2008) TNT, a free program for phylogenetic analysis. Cladistics 24: 774-786.

Goodman, S. M. \& Beanstead J. P. (eds) (2003) The Natural History of Madagascar. Chicago: University of Chicago Press.

Myers, N., Mittermeier, R. A., Mittermeier, C. G., da Fonseca, G. A. B. \& Kent, J. (2000) Biodiversity hotspots for conservation priorities. Nature 403: 853-858.

Nylander, J. A. A. (2005) MrModeltest v.2.2. Uppsala: Computer program distributed by the author.

Orange, A., James, P. W. \& White, F. J. (2001) Microchemical Methods for the Identification of Lichens. London: British Lichen Society.

Ramananjanahary, R. H., Frasier, C. L., Lowry, P. P., Rajaonary, F. A. \& Schatz, G. E. (2010) Madagascar's Endemic Plant Families. Species Guide. St. Louis: Missouri Botanical Garden.

Rambaut, A. \& Drummond, A. J. (2007) Tracer v1.4. Available from http://beast.bio.ed.ac.uk/.

Rauh, W. (1995) Succulent and Xerophytic Plants of Madagascar, Vol. 1. Mill Valley, California: Strawberry Press.

Rauh, W. (1998) Succulent and Xerophytic Plants of Madagascar, Vol. 2. Mill Valley, California: Strawberry Press.

Ronquist, F. \& Huelsenbeck, J. P. (2003) MrBayes 3: Bayesian phylogenetic inference under mixed models. Bioinformatics 19: 1572-1574.

Swofford, D. L. (1998) PAUP*. Phylogenetic Analysis Using Parsimony (* and Other Methods). Version 4. Sunderland, Massachusetts: Sinauer Associates. 
Tehler, A. (1993) The genus Sigridea (Roccellaceae, Arthoniales, Euascomycetidae). Nova Hedwigia 57: 417-435.

Tehler, A. (1997) Syncesia (Arthoniales, Euascomycetidae). Flora Neotropica 74: 1-48.

Tehler, A., Irestedt, M., Wedin, M. \& Ertz, D. (2010) The Old World Roccella species outside Europe and Macaronesia: taxonomy, evolution and phylogeny. Systematics and Biodiversity 8: 223-246.

Tehler, A., Ertz, D. \& Irestedt, M. (2013a) The genus Dirina (Roccellaceae, Arthoniales) revisited. Lichenologist 45: 427-476.

Tehler, A., Irestedt, M. \& Ertz, D. (2013b) Austroroccella, a new fruticose genus in the family Roccellaceae. Bryologist 116: 162-168.
Thor, G. (1990) The lichen genus Chiodecton and five allied genera. Opera Botanica 103: 1-92.

van den Boom, P. P. G. \& Giralt, M. (2012) Checklist and three new species of lichens and lichenicolous fungi of the Algarve (Portugal). Sydowia 64: 149207.

van den Boom, P. P. G., Brand, M., Ertz, D., Kalb, K., Magain, N., Masson, D., Schiefelbein, U., Sipman, H. J. M. \& Sérusiaux, E. (2011) Discovering the lichen diversity of a remote tropical island: a working list of species collected on Reunion (Mascarene archipelago, Indian Ocean). Herzogia 24: 325-349. 